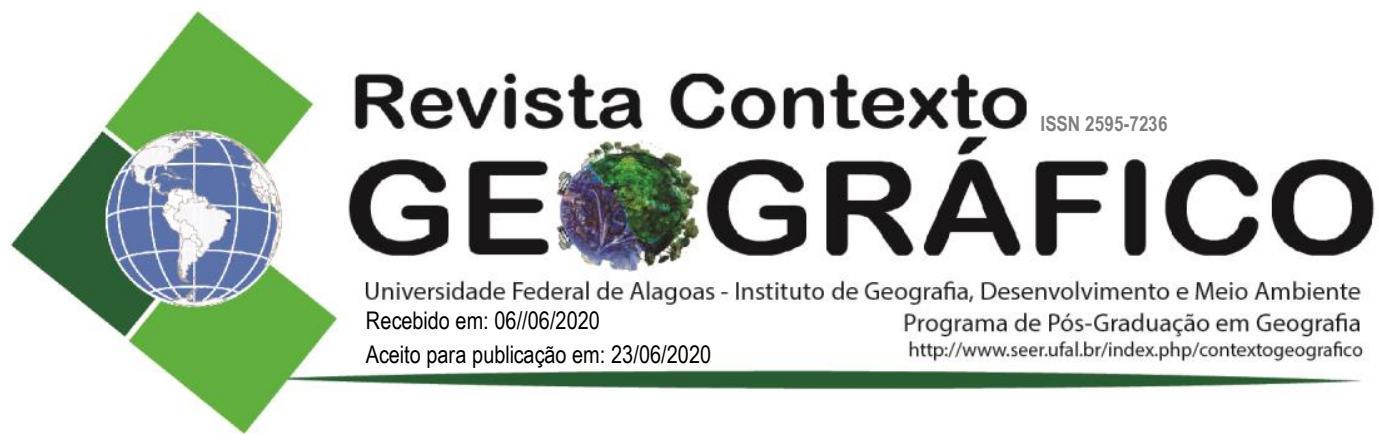

\title{
CONSTRUINDO O CONHECIMENTO GEOGRÁFICO A PARTIR DO MAPA MENTAL: EXPERIÊNCIA NA EDUCAÇÃO PARA A PESSOA IDOSA EM IMPERATRIZ/MA
}

Diego Armando de Sousa Paz

Economista. Graduando em Geografia. Bolsista de Apoio Técnico Institucional - UEMASUL. Membro do Grupo de Pesquisas Socioeconômicas do Maranhão - GPS

d.armando146@hotmail.com

Keilha Correia da Silveira

Profa. Adjunta da Universidade Estadual da Região Tocantina do Maranhão - UEMASUL. Membro do Grupo de Pesquisas Socioeconômicos do Maranhão - GPS. MA, Brasil keilha.kc@gmail.com

Allisson Bezerra de Oliveira

Prof. Adjunto da Universidade Estadual da Região Tocantina do Maranhão - UEMASUL. Membro do Grupo de Pesquisas Socioeconômicos do Maranhão - GPS. MA, Brasil.

allisonbzr@gmail.com

\begin{abstract}
RESUMO - O trabalho teve por objetivo discutir sobre a construção do conhecimento geográfico através de mapas mentais na Educação para a pessoa idosa. A discussão fundamentou-se na área de Ensino de Geografia com interfase na Cartografia escolar e Educação para a pessoa idosa, explicitando a relação Geografia-espaço-linguagem cartográfica que agrega conhecimento e considera o contexto em que se inserem os alunos. $\mathrm{O}$ trabalho envolveu uma parte empírica a partir de estudo de caso aplicado em Imperatriz/MA na Casa do Idoso Feliz, tendo como participantes um grupo de 135 idosos. Os resultados indicaram que o conhecimento geográfico começou a ser apreendido pelos idosos de forma mais efetiva, uma vez que foram trabalhados as memórias, as transformações do espaço vivido e os significados das ações deles no espaço. Mas ao mesmo tempo, os resultados mostraram limitações na percepção do espaço geográfico, que foram influenciadas por acentuadas deficiências na formação escolar e que influencia nas formas de apropriação desse espaço. Assim, concluiu-se que a utilização do mapa mental como ferramenta didático-pedagógica contribui para a construção do conhecimento geográfico na Educação para a pessoa idosa conferindo a esse conhecimento significância e apropriação.
\end{abstract}

Palavras-chave: Geografia. Mapa Mental. Educação para pessoa idosa. Imperatriz/MA.

\section{CONSTRUIR CONOCIMIENTO GEOGRÁFICO DESDE EL MAPA MENTAL: EXPERIENCIA EN EDUCACIÓN PARA ANCIANOS EN IMPERATRIZ/MA}

\begin{abstract}
RESUMEN - El objetivo de este trabajo era discutir la construcción del conocimiento geográfico a través de mapas mentales en Educación para ancianos. La discusión se basó en la enseñanza de geografía con interfase en la cartografía escolar y la educación para los ancianos, explicando la relación geografía-espacio-lenguaje cartográfico que agrega el conocimiento y considera el contexto en el que se insertan los estudiantes. El estudio incluyó una parte empírica de un estudio de caso aplicado en Imperatriz/MA en la Casa do Idoso Feliz, con un grupo de 135 personas mayores como participantes. Los resultados indicaron que el conocimiento geográfico comenzó a ser aprehendido por los ancianos de manera más eficaz, ya que se trabajaron recuerdos, transformaciones del espacio vivido y los significados de sus acciones en
\end{abstract}




\begin{abstract}
el espacio. Pero al mismo tiempo, los resultados mostraron limitaciones en la percepción del espacio geográfico, que fueron influenciadas por marcadas deficiencias en la educación escolar y que influyen en las formas de apropiación de este espacio. Así, se concluyó que el uso del mapa mental como herramienta didáctica-pedagógica contribuye a la construcción del conocimiento geográfico en Educación para las personas mayores, confiriendo este significado y apropiación de conocimientos.
\end{abstract}

Keywords: Geografía. Mapa mental. Educación para ancianos. Imperatriz/MA.

\title{
INTRODUÇÃO
}

A educação para pessoas idosas necessita de estratégias inovadoras, que permitam ao idoso se reconhecer como sujeito ativo no processo de ensino-aprendizagem, construindo um conhecimento significativo com base em suas experiências. Esse desafio foi à motivação para 0 presente estudo, com a investigação empírica realizada em Imperatriz/MA, na Casa do Idoso Feliz.

No processo de construção do conhecimento geográfico, estão presentes diferentes interações socioespaciais não lineares e localizadas, no qual importa a configuração espacial. Analisar tais interações é necessário para compreender a dinâmica de (re)produção do espaço geográfico, trata-se de uma ação complexa e fundamental para auxiliar o planejamento das ações da sociedade. Para tanto se dialoga com outras áreas do conhecimento, como a Cartografia e a Educação.

Nesse sentido, esse trabalho teve importância à medida que possibilitou, ao idoso, a construção do conhecimento geográfico do ponto de vista empírico e acadêmico que irá auxiliá-lo na compreensão do espaço vivido. Também teve importância para entender o Lugar geográfico no relacionamento do indivíduo com o mundo, levando-o a pensar criticamente, considerando aspectos afetivos e simbólicos.

O objetivo do trabalho foi discutir sobre a construção do conhecimento geográfico através de mapas mentais na Educação para a pessoa idosa. A discussão fundamentou-se na área de Ensino de Geografia com interfase na Cartografia escolar e Educação para a pessoa idosa, explicitando a relação Geografia-Espaço-Linguagem cartográfica que agrega conhecimento e considera o contexto em que se inserem os alunos.

O trabalho utilizou como método de pesquisa o estudo de caso, de cunho exploratório descritivo, com ênfase na análise qualitativa. Como procedimentos metodológicos foram selecionados: revisão bibliográfica, observação direta, questionário e mapa mental. A parte empírica foi realizada na Casa do Idoso Feliz, em Imperatriz/MA, tendo como participantes um grupo de 135 pessoas idosas.

Os resultados obtidos e as analisas realizadas são apresentadas nas cinco seções que se seguem. As três primeiras, de caráter mais teórico, procura, a partir da revisão de literatura, apresentar os principais conceitos referentes ao conhecimento geográfico com interfase na cartografia escolar e Educação para a pessoa idosa. Na seção seguinte, apresenta-se o estudo de caso, na Casa do Idoso Feliz e analisam-se os resultados da pesquisa. Os elementos analisados no decorrer do trabalho levam a uma conclusão geral sobre o uso de mapas mentais na construção do conhecimento geográfico no âmbito da educação para pessoas idosas.

\section{CONHECIMENTO GEOGRÁFICO: ESPAÇO E LUGAR}

Para além da aprendizagem escolar ou acadêmica, o conhecimento geográfico provoca a reflexão sobre o espaço vivido, sobre a Geografia cotidiana da prática social, e expõe os desafios sociais da contemporaneidade. Este entendimento pauta-se na ideia de que "o conhecer é um processo social 
e histórico, não um fenômeno individual e natural" (CAVALCANTI, 2005, p. 189), ou seja, o conhecimento é produzido em determinados períodos e se acumulam ao longo da história das sociedades.

A construção de conhecimento geográfico com pessoas idosas significa consolidar conhecimentos oriundos da relação direta com o espaço vivido, com as memorias, com a subjetividade do contexto socioeconômico e a mediação pedagógica. Nesse sentido, o conhecimento é espacialmente localizado, se concretizando em lugares específicos. Ou seja, construir conhecimento a partir da análise do lugar, do espaço no qual se desenvolvem as relações, a afetividade, a identidade dos alunos idosos.

\begin{abstract}
A produção espacial realiza-se no plano do cotidiano e aparece nas formas de apropriação, utilização e ocupação de um determinado lugar, num momento específico e, revela-se pelo uso como produto da divisão social e técnica do trabalho que produz uma morfologia espacial fragmentada e hierarquizada. Uma vez que cada sujeito se situa num espaço, o lugar permite pensar o viver, o habitar, o trabalho, o lazer enquanto situações vividas, revelando, no nível do cotidiano, os conflitos do mundo moderno (CARLOS, 2007, p. 20).
\end{abstract}

Dentro de uma perspectiva Tradicional/Clássica, a Geografia é entendida como a 'Ciência dos lugares'. Entretanto, a concepção de Lugar limitou-se à localização das coisas (SUERTEGARAY, 2001), ou seja, o conceito de Lugar foi concebido como uma porção do espaço na qual as pessoas habitam, associando-se à ideia de localidade, enquanto cenário físico, com uma localização geográfica determinada.

O conceito de Lugar não foi diretamente desenvolvido pela Geografia Tradicional, mas era estudado a partir da caracterização da paisagem e da região. Para Suertegaray (2001, p.30), o Lugar consistiria "[...] a partir da Cartografia, a expressão do espaço geográfico na escala local; a dimensão pontual. Por muito tempo, a Geografia tratou o Lugar nesta perspectiva e considerou-o como único e autoexplicável”.

Recentemente, o conceito de Lugar é resgatado pela Geografia Humanista, que associado à fenomenologia e ao existencialismo, analisa o termo de forma mais abrangente - visto como experiência, pois se refere a um tratamento geográfico do mundo vivido (SANTOS, 2002). Tendo uma preocupação mais subjetiva, o Lugar passa a ter valor simbólico que se soma as ações e as intenções da sociedade na formação do espaço.

Assim, a história é um elemento importante para a identificação do indivíduo com o Lugar, encarada como herança, raízes, memória que pode ser tanto individual quanto social e que reaparece nas relações pessoais com a simbologia do espaço vivido. Este compreendido por Santos (2002), como lócus no qual se articulam o processo de identificação e a história social do Lugar de forma dinâmica e transformadora. O Lugar "se superpõe dialeticamente ao eixo das sucessões, que transmite os tempos externos das escalas superiores e o eixo dos tempos internos, que é o eixo das coexistências, onde tudo se funde, enlaçando definitivamente, as noções e as realidades de espaço e tempo" (SANTOS, 2002, p.15).

A compreensão do conceito de Lugar baseado no espaço vivido fundamenta-se nas relações espaciais diretas, nas relações entre a cooperação e o conflito, no qual se produz o modo de existência social dos seres humanos (CARLOS, 2007). O conceito de Lugar transita em torno das interações e experiências humanas, que representa uma porção ou parte do espaço geográfico.

Como parte do espaço, o lugar é ocupado por sociedades que ali habitam e estabelecem laços tanto no âmbito afetivo, como também nas relações de sobrevivência. O lugar é fundamental no estudo da Geografia. Até o início do 
PAZ, D. A. A.; SILVEIRA, K. C.; OLIVEIRA, A. B.

\section{CONSTRUINDO O CONHECIMENTO GEOGRÁFICO A PARTIR DO MAPA MENTAL: EXPERIÊNCIA NA EDUCAÇÃO PARA A PESSOA IDOSA EM IMPERATRIZ/MA}

século XX, o lugar era usado para definir a Geografia, em seu sentido locacional, como simples conceito de localização espacial (ARCHELA et al., 2004, p.127).

Dito de outra forma, "quando o espaço nos é inteiramente familiar, torna-se lugar" (TUAN, 1983, p.83). A adaptação do indivíduo ou da sociedade a um espaço faz com que este adquira características afetivas, simbologias, sentimento de pertencimento. Nesse sentido, o Lugar irá ter papel na criação de vínculos e afetividade, e assim irá facilitar o reconhecimento espacial dos lugares onde viveu e/ou vive. A perspectiva é individual e precede à consciência, a intuição, a percepção do fenômeno, a subjetividade.

A percepção ou o uso dos sentidos para analisar o Lugar, é um método fenomenológico. "A percepção é tanto a resposta dos sentidos aos estímulos externos como a atividade proposital, na qual certos fenômenos são claramente registrados, enquanto outros retrocedem para a sombra ou são bloqueados" (TUAN, 2012, p.18).

'Na experiência, o significado de espaço frequentemente se funde com o de lugar. 'Espaço' é mais abstrato que 'lugar'. O que começa com espaço indiferenciado transforma-se em lugar à medida que o conhecemos melhor e o dotamos de valor" (TUAN, 1983, p.06). Uma pessoa pode conhecer um lugar tanto de modo íntimo como conceitual. Dessa maneira, ao ensinar os conceitos de espaço e lugar para o idoso é importante relembrar, de modo lúdico, os espaços vivenciados por eles, assim facilitando o ensino e a aprendizagem. Os idosos têm em suas memórias o conceito de lugar através de suas ligações íntimas com um determinado espaço vivido por eles.

Para Archela et al. (2004, p.131), "existem também considerações aos 'lugares de memória', que caracterizam por um meio das noções da aceleração da história e ruptura do elo entre a memória e a história". E consequentemente, pode-se compreender o lugar como algo inacabado e que está num processo de constante alteração, aberto e em movimento, necessitando, portanto, a ampliação do entendimento do espaço vivido para a forma como é concebido.

Nessa discussão, o mapa mental possibilita observar percepções variadas das pessoas, sobre o espaço em diferentes momentos na história, intimamente relacionado à memória social. Tais questões são muito ricas na educação para a pessoa idosa, devido à experiência de vida deles.

\section{A EDUCAÇÃO PARA A PESSOA IDOSA NO BRASIL}

A Educação para a pessoa idosa é vista neste trabalho de forma ampla, ultrapassando os limites formais da Educação e envolvendo questões singulares como, por exemplo, experiências de vida, relações sociais e familiares, cidadania, autonomia. Todas são questões precisas para a pessoa idosa e que na realidade brasileira não é raro serem negligenciadas pelo Estado, pela sociedade e pela família.

Como medida de proteção jurídica, em $1^{\circ}$ de outubro de 2003, foi sancionada a Lei $\mathrm{n}^{\circ} 10.741$ (BRASIL, 2003), que dispõe sobre o Estatuto do Idoso e regula os direitos específicos para às pessoas com idade igual ou superior a 60 (sessenta) anos. O Art. 20 estabelece que: "o idoso tem direito a educação, cultura, esporte, lazer, diversões, espetáculos, produtos e serviços que respeitem sua peculiar condição de idade" (BRASIL, 2003). Apesar de se tratar de direitos básicos previstos na Constituição Federal de 1988, o Estatuto confere notoriedade aos direitos as pessoas idosas.

Conforme previsto em lei, o poder público é um dos elementos que tem como obrigação garantir a dignidade humana dos idosos, assim como, efetivar os direitos constituídos por lei através de políticas públicas voltadas aos idosos. Apesar, do Estatuto do Idoso, criado em 2003 com o objetivo de garantir estes direitos, assim como, a Constituição Federal de 1988, ainda há um longo caminho entre o preconizado e o praticado. 
No que tange a educação para a pessoa idosa, o Estatuto do Idoso assegura a oferta pública e os parâmetros para a construção do currículo. O Art. 21 estabelece que "o poder público criará oportunidades de acesso do idoso à educação, adequando currículos, metodologias e material didático aos programas educacionais a ele destinados" (BRASIL, 2003). E o Art. 22 estabelece que "nos currículos mínimos dos diversos níveis de ensino formal serão inseridos conteúdos voltados ao processo de envelhecimento, ao respeito e à valorização do idoso, de forma a eliminar o preconceito e a produzir conhecimentos sobre a matéria" (BRASIL, 2003).

Paralelamente, Oliveira (1999, p.71) afirma que, "a sociedade coloca o velho em uma situação típica de marginalização social, na proporção em que ergue contra ele inúmeras barreiras sociais e desenvolve atitudes de preconceito e discriminação social". Tais discriminações e barreiras são aprofundadas justamente quando não se permite acesso à educação de qualidade nos vários estágios da vida, o que, por conseguinte acentua a vulnerabilidade quando se chega à terceira idade.

Em face da importância da educação para a formação da dignidade humana para as pessoas idosas, Freire (1967, p.36) afirma que "a educação das massas se faz, assim, algo de absolutamente fundamental entre nós. Educação que, desvestida da roupagem alienada e alienante, seja uma força de mudança e de libertação". A educação tem papel sistêmico na emancipação socioeconômica das pessoas nos diversos níveis de escolarização. Em consonância com esta perspectiva, o Estatuto do Idoso (BRASIL, 2003) no art. $8^{\circ}$, incisos, I, II, III e IV, afirma que:

\begin{abstract}
I - viabilizar a implantação de programa educacional voltado para o idoso, de modo a atender o inciso III do art. 10 da Lei no 8.842, de 4 de janeiro de 1994; II - incentivar a inclusão nos programas educacionais de conteúdos sobre o processo de envelhecimento; III - estimular e apoiar a admissão do idoso na universidade, propiciando a integração intergeracional; IV - incentivar o desenvolvimento de programas educativos voltados para a comunidade, ao idoso e sua família, mediante os meios de comunicação de massa;
\end{abstract}

De acordo com Cavalcanti (2012, p.45), "a escola é, nessa linha de entendimento, um lugar de encontro de culturas, de saberes (científicos e cotidianos), ainda que o seu trabalho tenha como referência básica os saberes científicos". Dessa forma, desenvolver o conhecimento geográfico para a pessoa idosa vai além de explorar os aspectos teóricos da matéria, e demanda uma abordagem significativa sobre os saberes cotidianos dos idosos, para através de metodologias lúdicas apresentarem a visão da Geografia de forma mais simples e interessante. A Geografia se constrói nas atividades diárias, os alunos e professores "ao circularem, brincarem, trabalharem pela cidade e pelos bairros, eles constroem lugares, produzem espaço, delimitam seus territórios" (CAVALCANTI, 2012, p.45). E os idosos, no que tange a produção do espaço, tem em seu cotidiano uma rica percepção de Geografia e representação do espaço.

É possível, embora este não seja o único objetivo, realizar um trabalho educativo, visando esclarecer os indivíduos sobre sua condição de cidadãos, quando se apropriam do mundo, do país, da cidade, da casa e, ao mesmo tempo, decifrando os inúmeros limites decorrentes das alienações. O trabalho consiste em discernir as experiências sociais e individuais e, assim, potencializá-las (DAMIANI, 1999, P.58).

Ensinar Geografia é treinar o olhar do aluno e do cidadão para perceber e se apropriar do conhecimento geográfico como ferramenta para a construção de suas experiências de vida. No 
caso das pessoas idosas, o ensino de Geografia deve partir do conhecimento existente e estimular o reconhecimento do espaço vivido para uma melhor compreensão de o que é Geografia e seu vasto campo de atuação. Trabalhar a relação homem com a realidade em que se insere era a pauta defendida por Freire (1967). Para o autor, "a partir das relações do homem com a realidade, resultantes de estar com ela e de estar nela, pelos atos de criação, recriação e decisão, vai ele dinamizando o seu mundo. Vai dominando a realidade. Vai humanizando-a. Vai acrescentando a ela algo de que ele mesmo é o fazedor" (FREIRE, 1967, p.43).

O homem, ao interagir com o espaço, treina seu olhar na leitura da realidade concreta e na produção de conhecimento. Dessa forma, o homem trava uma relação específica de sujeito para objeto, no qual esse conhecimento é expresso pela sua linguagem do cotidiano. A educação para uma classe "esquecida" pelo Estado e pela própria sociedade se faz necessária, pois os mesmos podemos retirar um rico depósito de conhecimento adquirido pelas experiências com a realidade (FREIRE, 1967).

E o ensino de Geografia, principalmente pela elaboração de representações espaciais, adotando o método de mapas mentais, se torna válido para se estabelecer uma relação de proximidade do sujeito e o objeto. Os conceitos da disciplina e as vivências espaciais, através das experiências de vida, são importantes. A Geografia não é só o que está no livro ou o que o professor fala, ela se constrói diariamente, ao vir para a escola a pé, de carro ou de ônibus, por exemplo, você mapeia o trajeto na sua cabeça. Portanto, o homem faz Geografia desde sempre. (KAERCHER, 1998).

Nesse sentido, é inevitável o diálogo com a visão socioconstrutivista do ensino, proposto por Vygotsky, na qual considera que o conhecimento do aluno deve ser considerado, pois ele é o "sujeito ativo de seu processo de formação e de desenvolvimento intelectual, afetivo e social" (CAVALCANTI, 2005, p.198).

\title{
MAPAS MENTAIS COMO FERRAMENTA DE ENSINO DA GEOGRAFIA
}

A construção de uma reflexão crítica e transformadora de um indivíduo deve estar pautada na transmissão de saberes, dessa forma, não adianta frequentar uma instituição de ensino formal se a mesma não fornece elementos para que o aluno possa compreender o meio em que vive. (RICHTER, 2011).

\begin{abstract}
Muito mais do que apenas ampliar o vocabulário do aluno, com a inserção de palavras como espaço geográfico, território, região, lugar, redes, paisagem, e etc., o trabalho didático de Geografia pauta-se pela relação desses saberes científicos na observação e compreensão do cotidiano. Desse modo, o aluno poderá utilizar o conhecimento geográfico para interpretar os diversos contextos que atuam e são responsáveis pela produção do espaço e que, indiretamente, afetam sua própria vivência (RICHTER, 2011, p.99).
\end{abstract}

Para o autor, discutir sobre Geografia e Educação dar mais possibilidade de formar cidadãos mais atentos às questões e práticas espaciais, e ao mesmo tempo, mais cientes do poder de transformação do espaço em que vivem. E a relação Geografia-espaço-linguagem cartográfica procura desenvolver uma capacidade no individuo de analisar o mundo de uma perspectiva espacial.

Dentre todas as possibilidades de leitura do espaço que podemos fazer, presente na análise da paisagem, no estudo dos diferentes territórios, na identificação das regiões ou na investigação da produção do lugar, temos condições de destacar a importante relação existente entre as práticas de leitura com a formação de uma linguagem, nesse caso uma linguagem 
PAZ, D. A. A.; SILVEIRA, K. C.; OLIVEIRA, A. B.
CONSTRUINDO O CONHECIMENTO GEOGRÁFICO A PARTIR DO MAPA MENTAL: EXPERIÊNCIA NA EDUCAÇÃO PARA A PESSOA IDOSA EM IMPERATRIZ/MA

espacial e que pode se chamar de cartográfica (RICHTER, 2011, p.104).

Logo, para orientação, localização, informação e comunicação à cartografia auxiliou e forneceu os instrumentos utilizados pelo homem. O mapa é um instrumento bastante utilizado na mais variadas atividades cotidianas da sociedade, sejam elas amadoras ou profissionais. Ou seja, o mapa é utilizado nas áreas sociais, culturais e turísticas, assim como, utilizado por administrador, viajante, professor entre outros. Para Almeida (2014, p. 16), "o mapa ocupa um lugar de destaque na Geografia, porque é ao mesmo tempo instrumento de trabalho, registro e armazenamento de informação, além de um modo de expressão e comunicação, uma linguagem gráfica".

O mapa é uma forma de linguagem mais antiga que a própria escrita. Povos pré-históricos, que não foram capazes de registrar os acontecimentos em expressão escritas, o fizeram em expressão gráfica, recorrendo ao mapa como modelo de comunicação. O mesmo acontece na atualidade com povos primitivos que não contam com um sistema de escrita, mas possuem mapas de suas aldeias e vizinhanças (ALMEIDA, 2014, p. 16).

A autora defende que a compreensão sobre o papel da Cartografia não deve ser restrita ao cunho técnico formal de transmissão de informações. É preciso ter olhar amplo e sem preconceitos, pois, assim com as demais ciências, a cartografia constrói conhecimento de forma dinâmica, dialogando com os fenômenos e o espaço geográfico. O cartógrafo também se preocupa com a leitura adequada e eficiente do mapa, na perspectiva fundamental do diálogo. Ou seja, o cartógrafo preocupa-se como o mapa irá ser utilizado pelos seus usuários e se esses usuários irão saber manusear essa ferramenta com eficiência.

Para a Cartografia, o espaço é fonte de informações para o seu objeto de estudo - o mapa. A ênfase está em levantar e representar as informações primárias do espaço e descobrir as melhores formas para esta tarefa, e nesse contexto, o mapeamento está ligado à percepção que se tem do espaço vivido. O mapa é, por excelência, parte do discurso geográfico e instrumento da análise geográfica, mas para efeito de análise adverte-se que o mapa transmite a visão de mundo de seu autor. (BARBOSA e SANTOS, 2017).

\footnotetext{
Na cartografia tivemos o crescimento da linha da Percepção e representação cognitiva do espaço. Esta corrente teórica da Cartografia Cognitiva teve no Brasil a contribuição da Psicologia Genética de Jean Piaget. Trabalhos como o de Lívia de Oliveira marcaram o início dos trabalhos desta linha. A Teoria da Cognição como método cartográfico envolve operações mentais lógicas como a comparação, análise, síntese, abstração, generalização e modelização cartográfica (BARBOSA e SANTOS, 2017, p.289-290).
}

Harley (1991) destacar a importância do uso da cartografia no ensino, e afirma que o mapa sempre foi imagem mental, ou seja, uma forma de ver. E ao pensar que o mapa é espelho do mundo, ou uma cópia fiel, passa-se a vê-lo como simulacro, algumas vezes mais importante que o território representado, dessa forma, uma (re)descrição do mundo em toda sua diversidade cultural. Segundo Kozel (2018, p.29), "os mapas, assim, constituem-se a partir da percepção e da representação de imagens mentais, o que vem despertando para necessidade de se compreenderem os complexos aspectos socioculturais do mundo atual". Logo, pensar o mapa como análise sociocultural necessita de uma análise intrínseca entre sociedade e espaço geográfico. 
PAZ, D. A. A.; SILVEIRA, K. C.; OLIVEIRA, A. B.

\section{CONSTRUINDO O CONHECIMENTO GEOGRÁFICO A PARTIR DO MAPA MENTAL: EXPERIÊNCIA NA EDUCAÇÃO PARA A PESSOA IDOSA EM IMPERATRIZ/MA}

O conceito de mapas mentais, na perspectiva da informação, memorização e planejamento, origina-se nas pesquisas realizadas pelo psicólogo e consultor educacional britânico Tony Buzan. Baseado nos conhecimentos gregos sobre os sistemas de memorização, utilizando a criatividade e a associação de ideias, relaciona-os aos estudos sobre o funcionamento do cérebro. A partir desses estudos, elabora uma ferramenta com o intuito de organizar o pensamento, que denominou mapa mental. (KOZEL, 2018, p.31).

A materialização do mapa mental, de acordo com Kozel (2018), consiste na elaboração de um desenho em uma folha de papel em branco, onde, através de símbolos, serão organizadas as informações e as ideias de maneira criativa e lúdica. O mapa mental constitui-se como um recurso para representar detalhadamente as conexões existentes entre as informações, que muitas vezes se acham fragmentadas e pulverizadas, tornando-as mais visíveis. As informações, oriundas das representações cognitivas, ficariam assim retidas na mente e seriam utilizadas na medida em que o sujeito se move num determinado espaço. Por isso, a prática com o espaço é fundamental no processo de desenvolvimento.

As pesquisas empíricas sobre percepção e cognição geográfica revelam uma compreensão ampla sobre o que significa mapa mental. O mapeamento cognitivo é considerado produto de processos psicológicos sobre o espaço vivenciado codificado pela mente. Consequentemente, o trabalho proposto foca na importância, para os idosos, do entendimento de que a Geografia, enquanto ciência espacial, irá auxilia-los na compreensão do espaço vivido, assim como, entender o lugar no relacionamento com o mundo que implica reconhecer a necessidade de pensar o lugar criticamente, considerando os seguintes aspectos como localização, espírito do lugar, sentido do lugar, raízes e enraizamento, lar, a construção do lugar (KOZEL, 2018).

Desta forma, é importante o estudo de mapa mental focado na relação entre o espaço e o comportamento humano no ambiente, refletindo fundamentos cognitivos, afetivos e simbólicos como importantes indicadores do lugar. O idoso, no convívio do espaço geográfico em que se insere, estabelece um sentimento de afetividade com esse mesmo local, assim, atribuindo símbolos sobre o espaço no qual está inserido.

Para compreender as representações sob essa perspectiva, é preciso não só considerar os processos cognitivos advindos da percepção como vislumbrar o ser humano na sua interação com o mundo vivido, valorizando singularidades e peculiaridades, concebendo-o como produtor de culturas em sua vivência espacial, transformando o espaço em lugar (KOZEL, 2018, p.41).

Richter (2018) adverte que, mais importante do que apenas localizamos um determinado fenômeno numa representação cartográfica, é fundamental o desenvolvimento de atividades de leitura e interpretação que permita ao idoso, enquanto aluno, entender a produção de um dado contexto no espaço. A produção dos mapas mentais pelos idosos vem estabelecer a compreensão do processo de produção do espaço, em que o próprio homem é o responsável pela construção e transformação do meio.

Mapas mentais são imagens espaciais que as pessoas têm de lugares conhecidos, direta ou indiretamente. As representações espaciais mentais podem ser do espaço vivido no cotidiano, como por exemplo, os lugares construídos do presente ou do passado; de localidades espaciais distantes, ou ainda, formadas a partir de acontecimentos sociais, culturais, históricos e econômicos, divulgados nos meios de comunicação (ARCHELA et al. 2004, p.127). 
Os mapas mentais são representações do vivido. Eles são representações construídas ao longo do tempo social e em lugares experienciados cotidianamente. Dessa forma, os mapas mentais revelam como o Lugar é compreendido e vivido, sobretudo, dentro de uma continuidade histórica estabelecida sobre a memória. (ARCHELA et al., 2004).

\section{ESTUDO DE CASO SOBRE O USO DE MAPAS MENTAIS}

Como investigação empírica, foi estudada a construção do conhecimento geográfico para pessoas idosas a partir do uso de mapa mental na Casa do Idoso Feliz em Imperatriz/MA. O estudo de caso foi realizado entre os meses de dezembro/2018 a maio/2019, e envolveu atividades de ensino com aulas dialogadas, rodas de conversa, oficinas e atividades lúdicas, todas abordando temas previamente definidos sobre Geografia e Espaço geográfico a partir do cotidiano deles. O público-alvo da investigação foram 135 pessoas idosas participantes das atividades de ensino e frequentadores da instituição.

A Casa do Idoso, criada em 1994, com base na lei $n^{\circ} 8.842 / 1994$ e no Art. $4^{\circ}$ do decreto de $n^{\circ}$ 1.948/1996, localiza-se no centro da cidade de Imperatriz (ver Figura 1) e atende em média 1.200 idosos. Legalmente, trata-se de uma instituição pública municipal compreendida por uma modalidade não asilar de atendimento, ou seja, um centro de convivência destinado à permanência diurna da pessoa idosa. Na Casa do Idoso Feliz, são desenvolvidas atividades físicas, laborativas, recreativas, culturais, associativas, de educação para a cidadania, e realizados exames e acompanhamentos de saúde nas áreas de ginecologia, urologia, enfermaria, fisioterapia, terapia ocupacional. Em outras palavras, a instituição tem como objetivo gerar atividades que venham contribuir para o processo de desenvolvimento saudável da pessoa idosa, assim, também como fornecer orientação e acesso aos serviços públicos os quais necessita.

Figura 1. Localização da Casa do Idoso Feliz no município de Imperatriz/MA

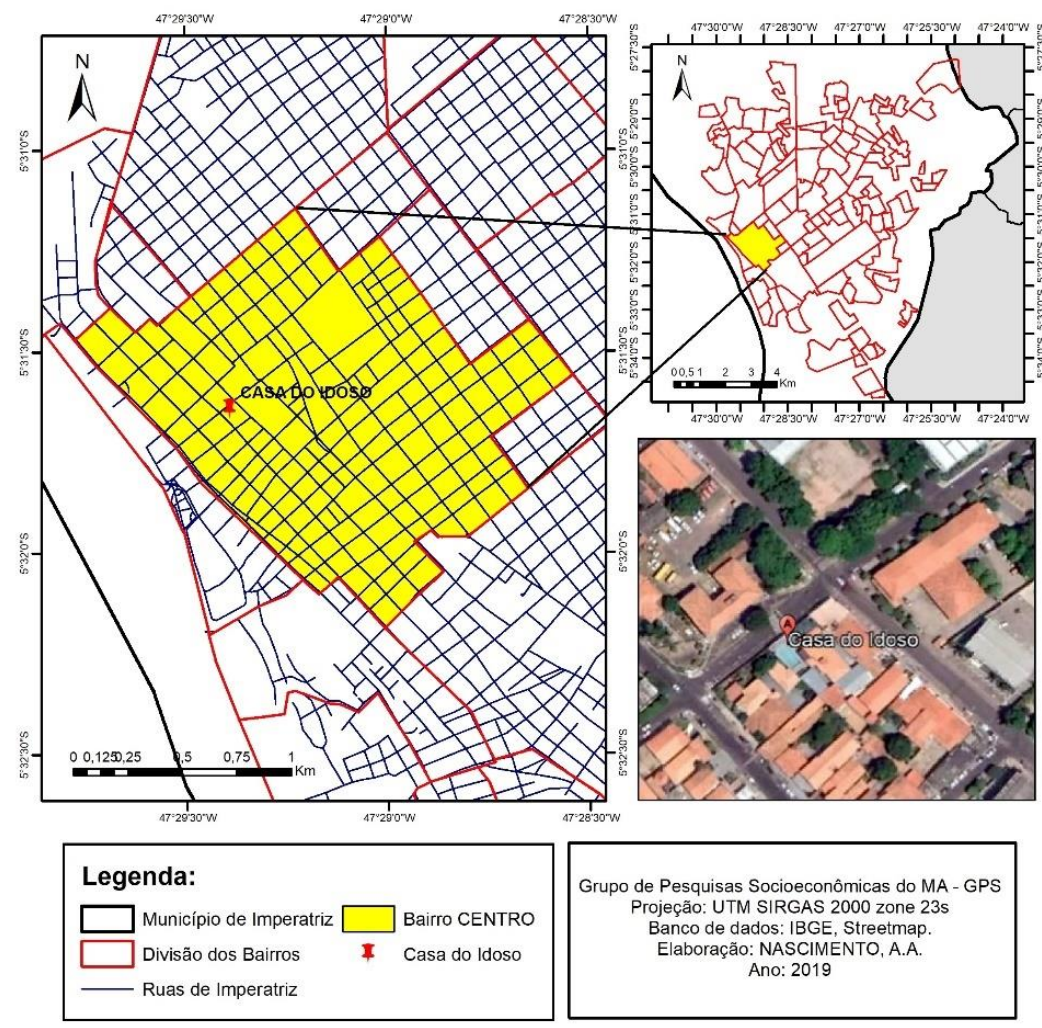

Org. Autores (2019) 
Os resultados e análises do estudo de caso foram desenvolvidos a partir de dois eixos. O primeiro refere-se ao perfil socioeconômico dos participantes, que foi construído com o intuito de avaliar algumas questões que influenciaram diretamente no processo de ensinoaprendizagem, como por exemplo, local de residência e grau de escolaridade. Como instrumento de coleta de dados, foram utilizados questionário e observações diretas realizadas ao longo das atividades de ensino.

Do total de 135 pessoas idosas participantes, foram coletadas e analisadas informações de 99 pessoas, que mostrou um perfil muito heterogêneo e significativo. Do grupo analisado, todos tinham idade igual ou superior a 60 anos, sendo que 54\% tinham idade entre 60 e 69 anos e $46 \%$ tinham entre 70 e 90 anos. Sobre o local de residência, 95 pessoas residiam no município de Imperatriz/MA, mais especificamente no perímetro urbano, e quatro pessoas residiam em outros municípios. Apesar da Casa do Idoso Feliz ter uma área de abrangência municipal muitos frequentadores são moradores locais e um percentual muito pequeno são residentes de outros municípios.

Essa alta concentração de idosos morando no perímetro urbano de Imperatriz pode ser explicada pela precariedade do transporte público municipal e intermunicipal. Destaca-se que $57 \%$ dos idosos, que se deslocam até a instituição, utilizam o transporte público, e $11 \%$ afirmam ir à instituição andando. A relação de proximidade, o tempo de deslocamento, o itinerário e os horários de funcionamento das linhas de ônibus também influenciam.

O quadro apresentado mostra que por residirem no perímetro urbano de Imperatriz, o grupo de 95 pessoas possui um cotidiano pautado em questões urbanas, fato que deu direcionamento aos temas abordados nas atividades de ensino e nos desenhos dos mapas mentais.

Ao percorrer a cidade, os idosos adquirem símbolos e representações ao longo do tempo que irá redimensionar seus olhares a conceitos de Geografia como Lugar e Espaço vivido. Isso é um traço da natureza humana, que a partir da sua interação com o mundo vivido valoriza singularidades e peculiaridades assim concebendo-o como produtor de cultura em sua vivência espacial, transformando o Espaço em Lugar (KOZEL, 2018). O conhecimento geográfico a ser construído envolveu questões de localização e deslocamento, reconhecimento dos equipamentos públicos, identificação do espaço vivido, reconhecimento do espaço institucional da Casa do Idoso Feliz, entre outros.

Outra questão avaliada no perfil socioeconômico foi o grau de escolaridade. Trata-se de um elemento muito importante para o estudo de caso, pois repercutem no andamento e nos resultados das atividades realizadas nas aulas e oficinas de ensino de Geografia. Dos resultados apresentados na Figura 2, destaca-se que 65 pessoas idosas possuíam o ensino fundamental incompleto, uma pessoa possuía ensino superior completo e uma pessoa idosa possuía ensino superior incompleto, seguido de 10 pessoas não alfabetizadas.

As possíveis dificuldades no processo de ensino-aprendizagem, indicadas a partir dos dados da Figura 2, foram ponderadas e direcionaram a organização dos temas de aula, o tipo de atividades de aprendizagem e principalmente os comandos delas. $\mathrm{Na}$ observação direta, foi percebida muita dificuldade de interpretação e raciocínio, aproximadamente $80 \%$ dos participantes tinham dificuldades em interpretação de textos simples. O grau de escolaridade refletiu muito nas formas com que os idosos atendidos apreenderam o conteúdo e conseguiram associá-lo a sua vida diária.

O segundo eixo de resultados e análises do estudo de caso refere-se aos desenhos de mapas mentais. Antes de efetivamente serem realizados pelo grupo de idoso, foi perguntado, no questionário do perfil socioeconômico, se eles conseguiriam desenhar o percurso que faziam da residência até a Casa do Idoso Feliz. Como resposta, 66 idosos afirmaram que não conseguiriam fazer o desenho e 33 afirmaram que sim (ver Figura 3). 
PAZ, D. A. A.; SILVEIRA, K. C.; OLIVEIRA, A. B.
CONSTRUINDO O CONHECIMENTO GEOGRÁFICO A PARTIR DO MAPA MENTAL: EXPERIÊNCIA NA EDUCAÇÃO PARA A PESSOA IDOSA EM IMPERATRIZ/MA

Figura 2. Nível de escolaridade

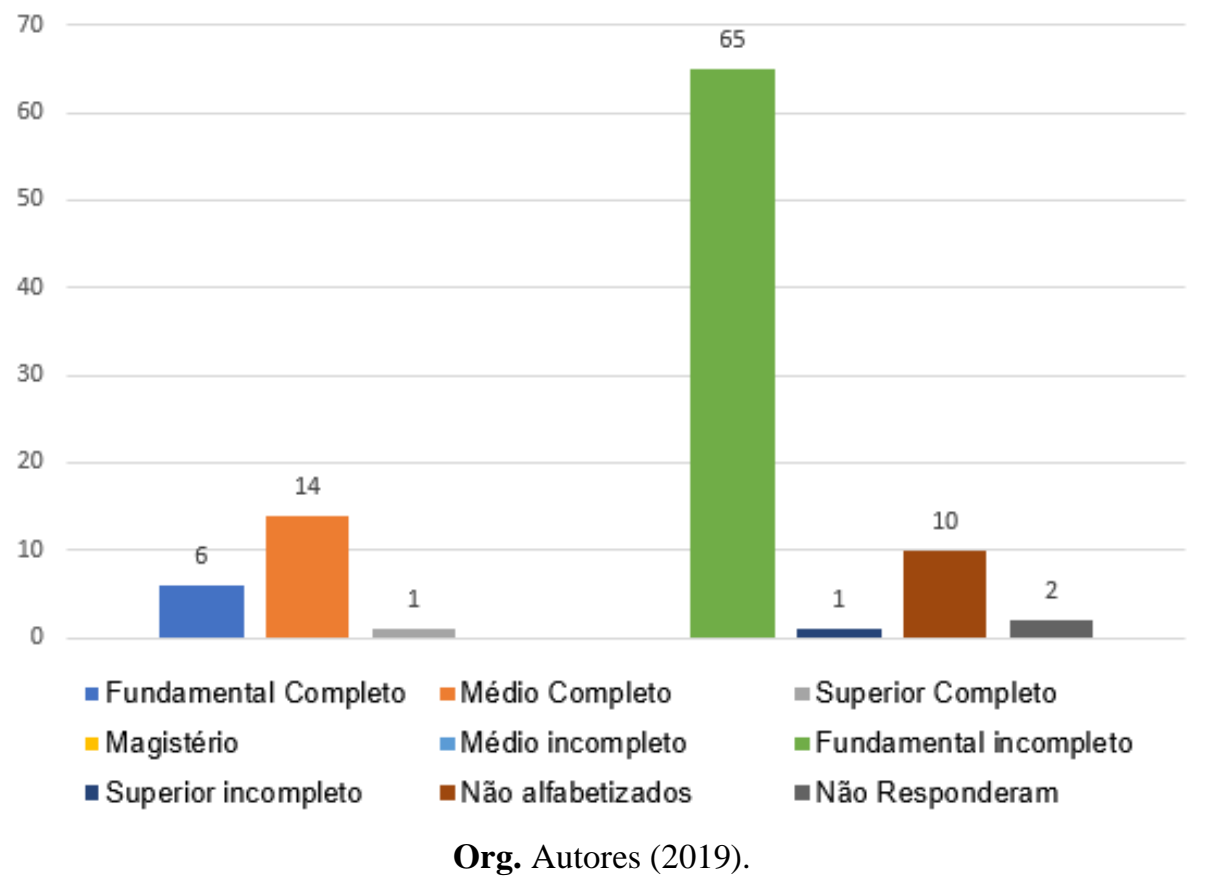

Figura 3. Quantitativo de idosos que afirmaram não conseguir desenhar um mapa do percurso de suas casas até a Casa do Idoso Feliz

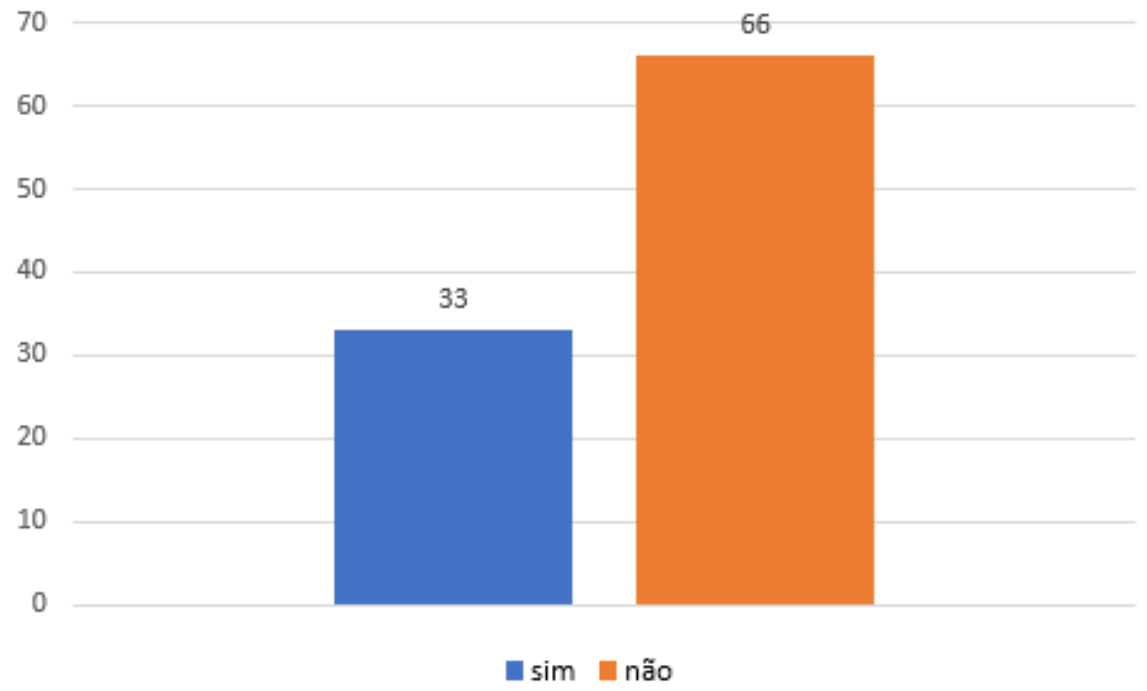

Org. Autores (2019)

Esse foi um dado interessante, pois os idosos realizavam o percurso corriqueiramente, eles possuíam na memória esse percurso. Ou seja, possuíam o conhecimento, mas por algum motivo acreditaram que não tinham e tiveram vergonharam de se expor e errar. Ao mesmo tempo o dado é representativo, principalmente no que tange a percepção do espaço e a interação que se desenvolve nele. Esses são pontos muito importantes para o exercício da cidadania, objeto da educação brasileira.

Ciente da provável resistência, antes da produção dos mapas mentais, foi ministrada uma palestra na qual se expos a concepção sobre mapa mental, os benefícios para o processo ensino-aprendizagem, os 
PAZ, D. A. A.; SILVEIRA, K. C.; OLIVEIRA, A. B.
CONSTRUINDO O CONHECIMENTO GEOGRÁFICO A PARTIR DO MAPA MENTAL: EXPERIÊNCIA NA EDUCAÇÃO PARA A PESSOA IDOSA EM IMPERATRIZ/MA

principais elementos cartográfico e geográfico (ver Figuras 4 e 5). Em seguida, foram realizadas oficinas semanais para produção dos desenhos dos mapas conforme ilustra a Figura 6.

Figura 4. Palestra sobre Orientação e localização geográfica.

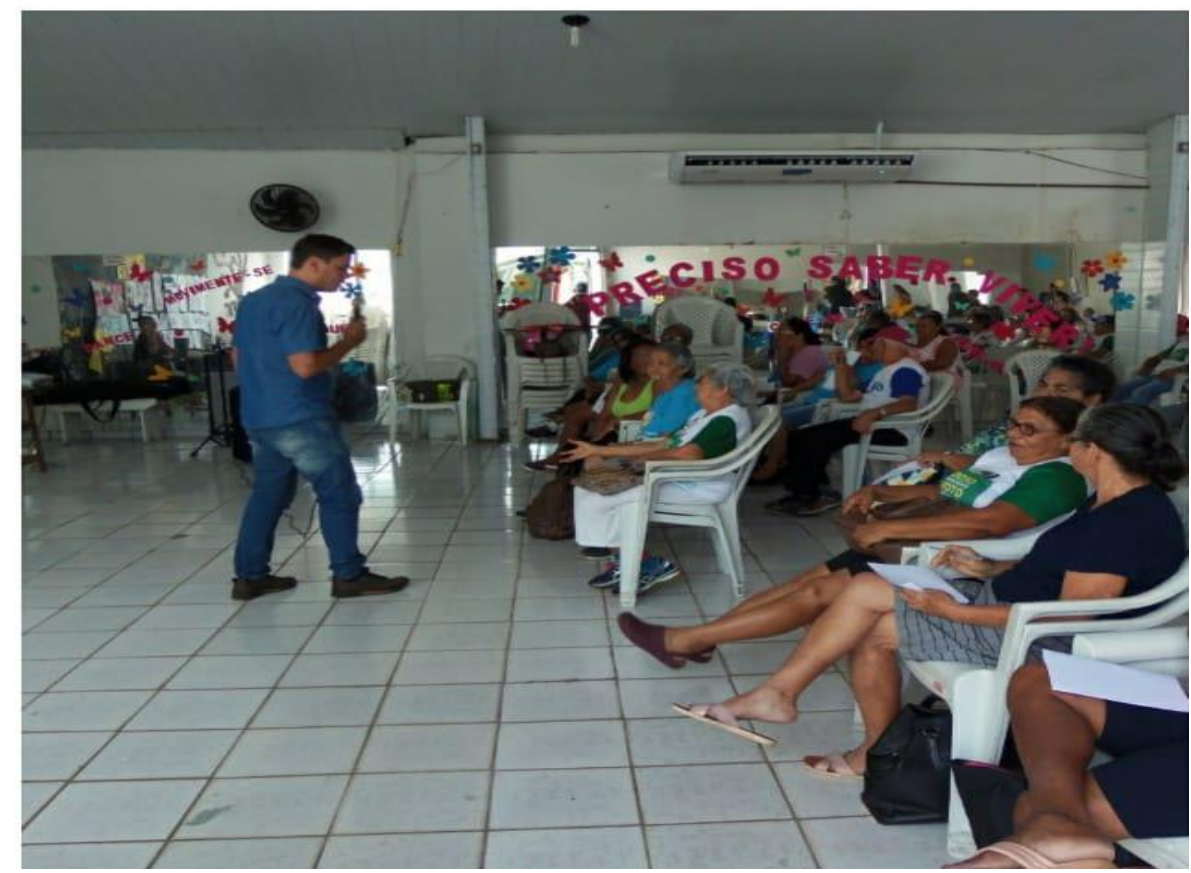

Org. Autores (2019)

Figura 5. Palestra sobre mapa mental.

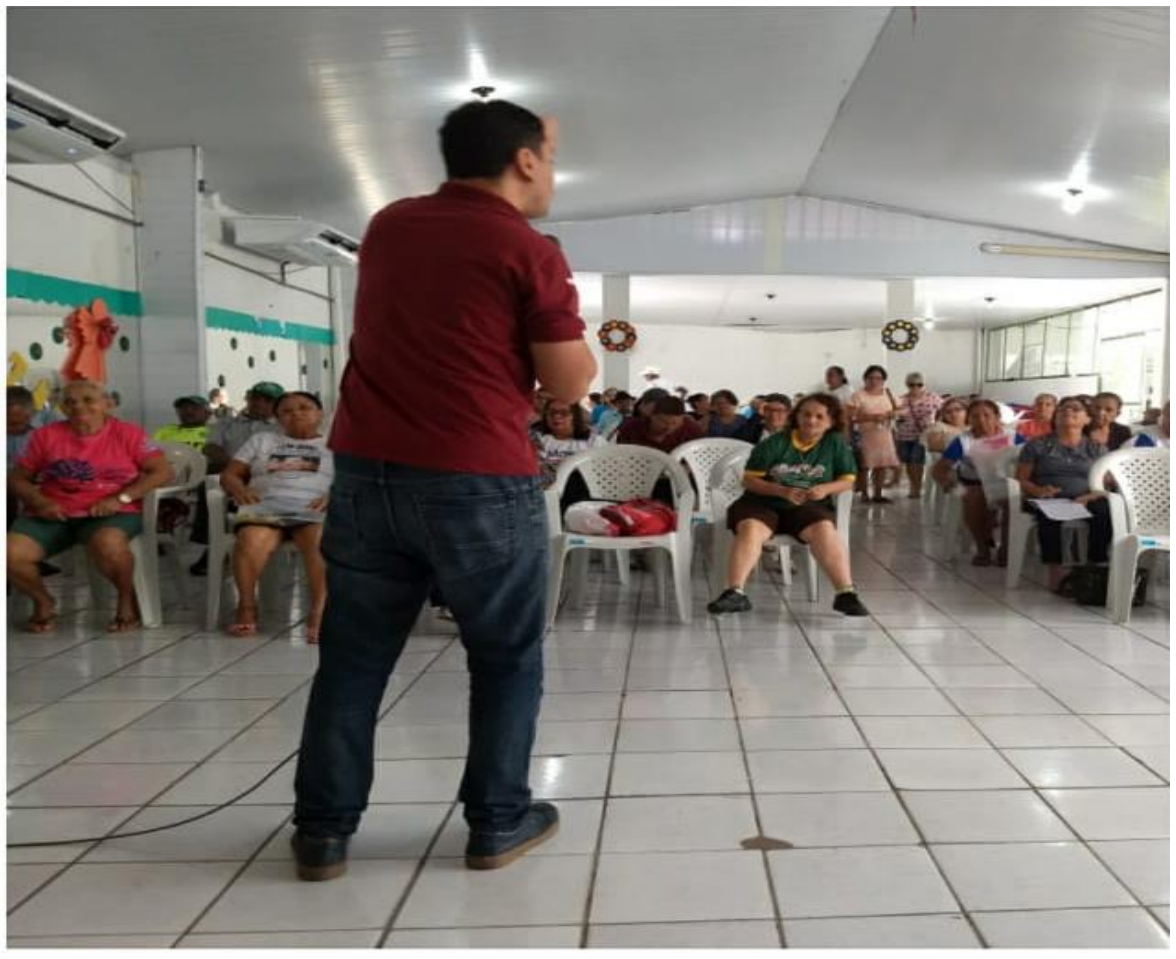

Org. Autores (2019) 
Figura 6. Oficina para a construção de mapas mentais.

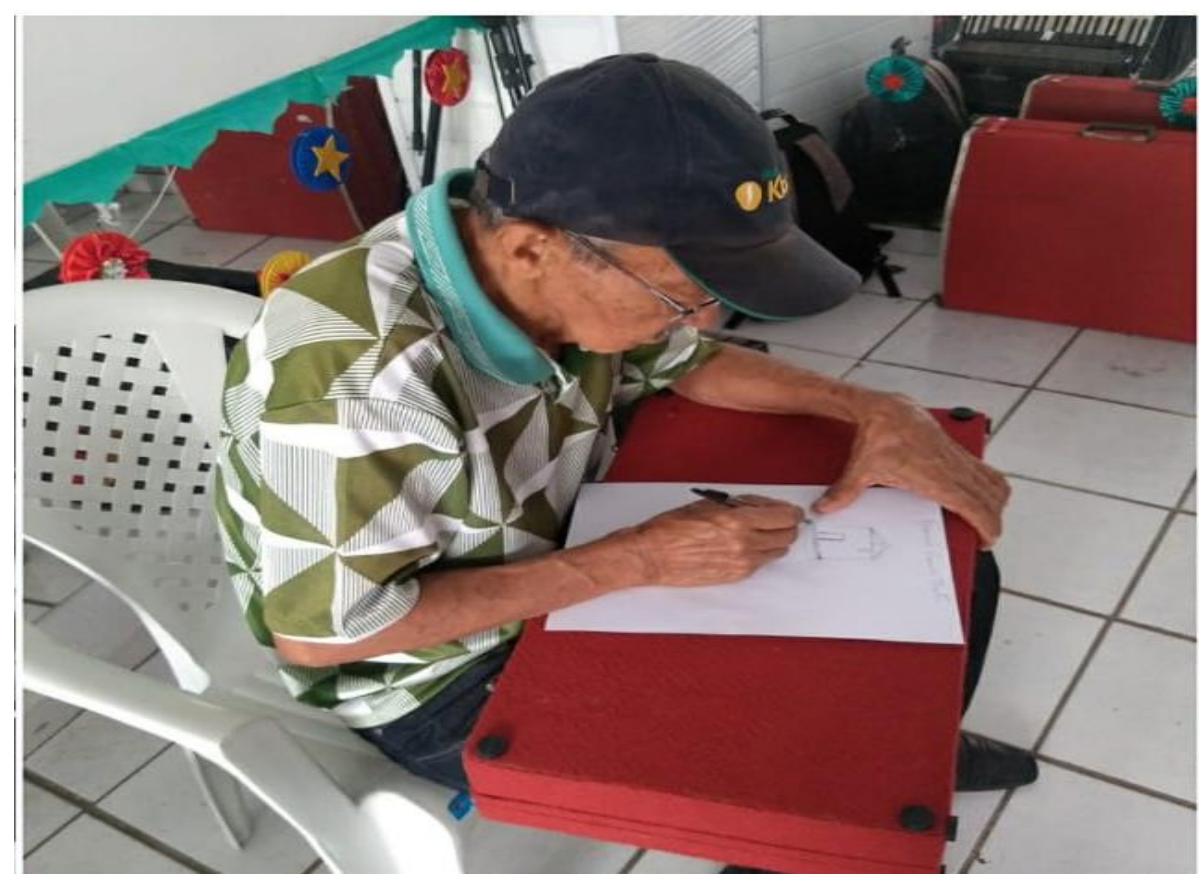

Org. Autores (2019).

As oficinas destinavam-se ao exercício prático para materialização dos conhecimentos, sendo estimulada a criatividade, a interação, a coletividade, entre outras coisas. $\mathrm{O}$ momento era descontraído e tinha muita participação dos idosos, mas alguns problemas de infraestrutura dificultavam a realização das atividades, como a falta de mobiliário adequado para apoiar o material didático, conforme mostrado na Figura 6.

Nesse exercício, foi utilizada imagem como instrumento didático para estimular e até mesmo auxiliar na produção dos mapas mentais. As imagens selecionadas mostravam as transformações urbanas da cidade de Imperatriz/MA ao longo do tempo, como mostra a Figura 7.

A imagem era projetada e os idosos descreviam as mudanças em cada período. Nesse momento, a participação era intensa, com muita discussão sobre o espaço representado e as interações que ocorriam. Já nos momentos para desenhar os mapas mentais houve muita resistência, e os motivos foram variados. Alguns idosos justificavam que não sabiam desenhar, outros diziam que não sabiam escrever, outros simplesmente não desenhavam. Em média 30 idosos, finalizaram um mapa mental do trajeto entre a residência e a Casa do Idoso Feliz.

Entre a primeira e a última oficina, foi observada uma evolução no processo de construção dos mapas mentais, tanto no sentido artístico do desenho quanto na compreensão de elementos cotidianos, visíveis e intangíveis, do espaço. Trazer, através de atividades lúdicas, exemplos simples do cotidiano dos idosos, sobretudo, enfatizando as transformações no espaço ao longo dos anos se mostrou significativamente satisfatório. Na produção dos mapas mentais, alguns simbolismos são comuns na percepção do espaço vivido como praças, igrejas e mesmo o sentido do tráfico das principais ruas. 
Figura 7. Foto aérea Praça Tiradentes em 1970 e na atualidade

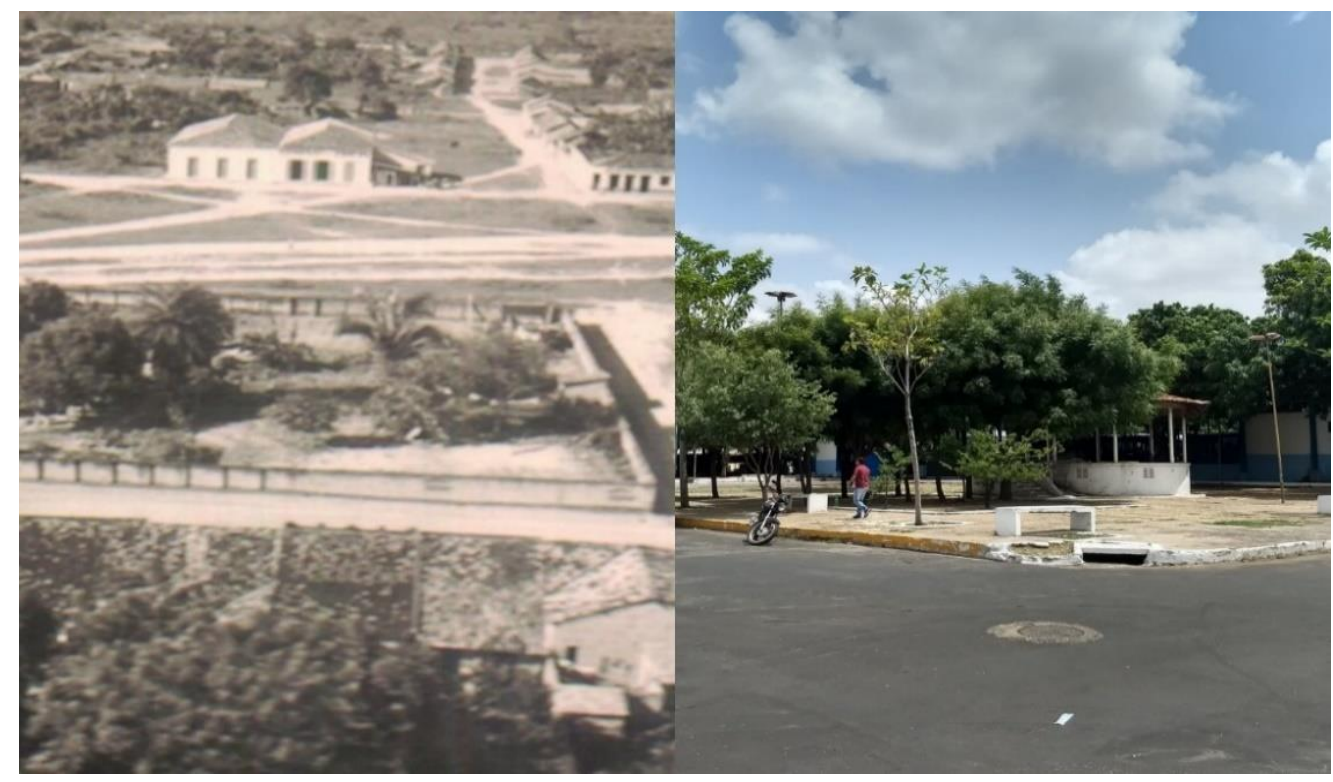

Org. Autor (2019).

A Figura 8 mostra dois mapas mentais sobre o percurso entre as residências dos idosos e a Casa do Idoso Feliz. Alguns elementos sobre orientação e localização geográfica foram percebidos. Os alunos dedicaram-se precisamente a identificar o layout e os nomes das vias públicas pelas quais passavam. Os mapas também mostram uma visão parcial do trajeto ou a mais representativa. Por exemplo, o mapa do lado esquerdo identifica apenas as ruas do lado direito da Gonçalves Dias, como se do outro lado não houvesse urbanização. Já o mapa do lado direito identifica literalmente o trajeto da residência para a instituição, o caminho inverso não foi mostrado.

Figura 8. Mapas mentais do percurso entre as residências e a Casa do Idoso Feliz.

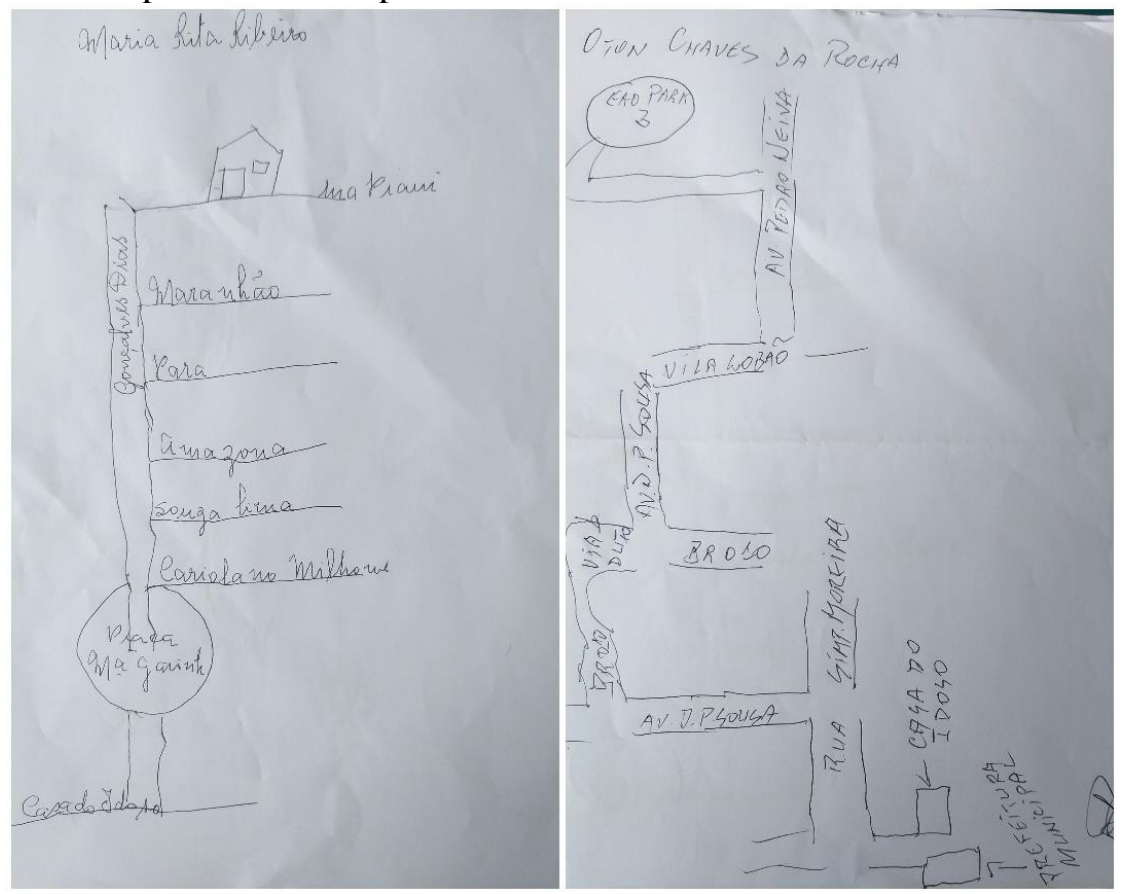

Org. Autor (2019). 
A Figura 9 mostra uma análise do espaço geográfico da cidade de Imperatriz/MA. Diferentemente da Figura anterior, os elementos desenhados indicam mais afetividade dos idosos quanto ao lugar vivido por eles. O desenho expressa os aspectos da cidade de Imperatriz que foram marcantes na vida dos idosos. Observa-se o apego pelos símbolos como o rio Tocantins, a Igreja Católica Santa Tereza D'ávila, a primeira igreja da cidade, e o prédio que destacam o desenvolvimento de Imperatriz/MA.

Figura 9. Mapas mentais sobre os aspectos da cidade de Imperatriz/MA.

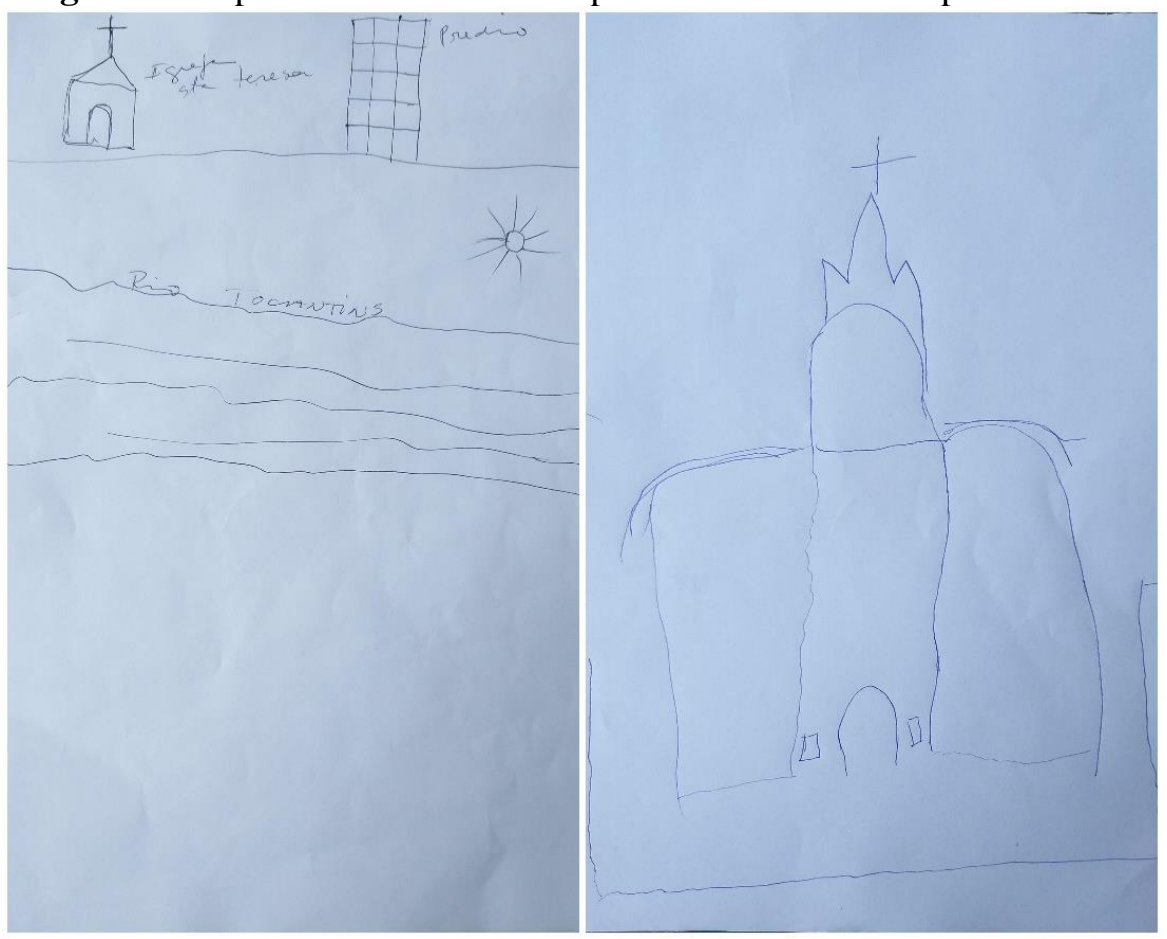

Org. Autor (2019).

$\mathrm{O}$ desenho das residências foi outro tema desenvolvido nas oficinas. $\mathrm{O}$ intuito foi identificar peculiaridades no que diz respeito à afetividade com o lugar em que residem, e observar a compreensão do idoso sobre localização espacial. Esperava-se que os desenhos identificassem os elementos próximos à residência e que eram percebidos pelos idosos. Mas, houve muita resistência e os desenhos identificaram apenas a residência e a rua em que se localiza, como mostra a Figura 10. Apesar disso, nos mapas produzidos, observa-se o domínio de princípios básicos de localização geográfica.

Analisando o trabalho por completo percebe-se que o mapa mental tem um uso didáticopedagógico importante não apenas para construção do conhecimento geográfico, mas também para ativar as memórias e para socializar experiências, tudo de forma lúdica. O conhecimento produzido tem significância e por esse motivo tem maior probabilidade se ser internalizado, consolidando o processo de aprendizagem.

O mapa mental mostrou-se uma ótima ferramenta para estudar o espaço vivido dos idosos, principalmente por que permitiu representar espacialmente as áreas ou lugares que eles consideravam importante ou que possuíam algum significado, tornando o desenho único e personalizado. Ao fim, o mapa mental cumpriu também o papel de conscientizar os idosos sobre a importância da construção socioespacial da realidade que os rodeiam, pautada na afetividade e no conhecimento geográfico entrelaçado aos conceitos de Lugar e Espaço vivido no qual a Geografia discute em seus conteúdos. 
Figura 10. Mapa mental sobre a localização das residências.

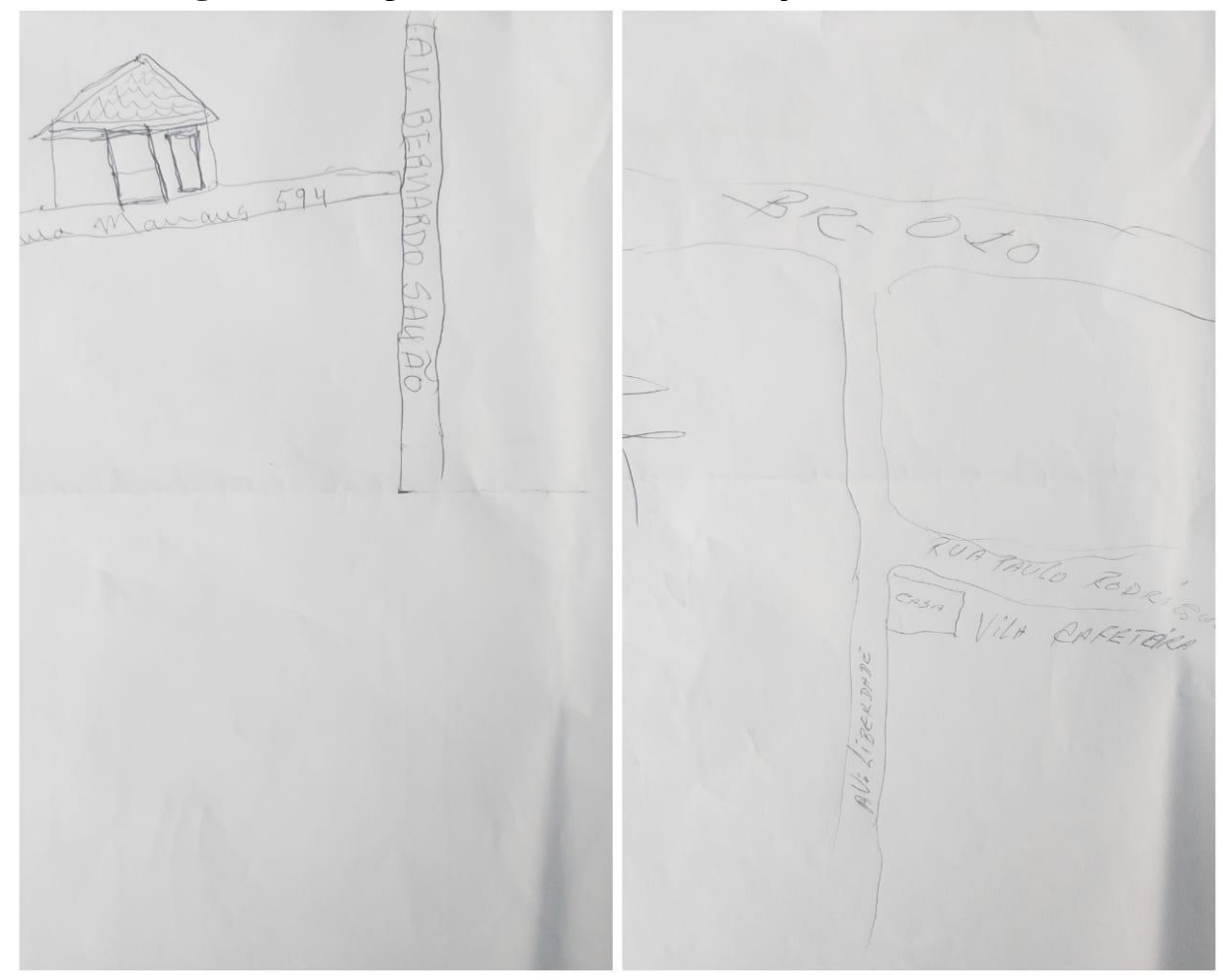

Org. Autor (2019).

\section{CONSIDERAÇÕES FINAIS}

O trabalho discutiu sobre a construção do conhecimento geográfico para a pessoa idosa através do uso de mapa mental. Os argumentos expostos assumiram o discurso da importância didáticopedagógica da ferramenta para o ensino e a construção do conhecimento geográfico, historicamente produzido e imbricado as relações sociais e afetivas no espaço vivido.

Dada sua capacidade de representação do mundo real relacionado à construção do raciocínio geográfico, o mapa mental permitiu associar conhecimento científico apreendido nas aulas e elementos provenientes do mundo vivido no cotidiano. Essa associação foi trabalha, em todas as atividades de ensino com os idosos, e foi percebida sua importância na construção do conhecimento geográfico à medida que eles relacionavam cada elemento das atividades ao seu cotidiano, associando em seguido às bases teóricas requeridas pelo conhecimento científico.

A construção dos mapas mentais representou um processo longo. E em muitos momentos, os idosos demonstraram resistência à participação na atividade ou na finalização do desenho. Esses problemas já eram esperados, devido à falta de familiaridade com a ferramenta, o curto tempo para sensibilização, à infraestrutura não adequada para fazer a atividade de desenho e a falta de articulação com as demais atividades realizadas na instituição.

Através da análise dos mapas mentais, observou-se uma rica percepção do espaço geográfico pelos idosos, apesar de apresentarem limitações na representação desse espaço, determinando um nível acentuado de analfabetismo cartográfico.

Apesar dos problemas enfrentados, os resultados obtidos foram satisfatórios. O uso dos mapas mentais permitiu impulsionar conceitos e práticas da ciência geográfica para o desenvolvimento educacional dos idosos. Nesse sentido, os Mapas Mentais propiciaram a reflexão sobre o tema proposto a partir do mundo vivido, tendo grande importância na associação do conhecimento científico e o conhecimento tradicional dos idosos. 
Os resultados reiteram que o uso de mapas mentais, como ferramenta didático-pedagógica, auxiliam no processo de educação para a pessoa idosa. Dentre os efeitos positivos destacam-se: a leitura do espaço vivido, interpretação do Lugar geográfico e o reconhecimento das suas ações no espaço e na construção de conhecimento.

\section{REFERÊNCIAS}

ALMEIDA, R. D. Cartografia escolar. 2a ed. São Paulo, SP: Contexto, 2014.

ARCHELA, R. S; GRATÃO, L. H. B; TROSTDORF, M. A. S. O Lugar dos Mapas Mentais na representação do Lugar. Geografia: Londrina, v.13, n.1, jan./jun. 2004.

BARBOSA, R. dos S; SANTOS, F. K. S. dos. A cartografia e as correntes do pensamento geográfico. Revista de Geografia (Recife), v.34, n.3, p.277-290, 2017.

BRASIL. Decreto nº 1948/1996. Política Nacional do Idoso. Brasília: DF, julho de 1996.

BRASIL. Lei no 1074/2003. Estatuto do Idoso. Brasília: DF, outubro de 2003.

BRASIL. Lei no 8842/1994. Política Nacional do Idoso. Brasília: DF, janeiro de 1994.

BRASIL. Secretaria de Educação Fundamental. Parâmetros Curriculares Nacionais: Geografia. Brasília: MEC/ SEF, 1998.

CARLOS, A. F. A. O Lugar no/do Mundo. São Paulo: FFLCH, 2007.

CAVALCANTI, L. de S. O ensino de geografia na escola. Campinas, SP: Papirus, 2012.

CAVALCANTI, L. de S. Cotidiano, mediação pedagógica e formação de conceitos: uma contribuição de Vygotsky ao ensino de geografia. In: Educação geográfica e as teorias de aprendizagens. Cadernos Cedes, n 66. São Paulo: Campinas, 2005.

DAMIANI, A. L. A geografia e a construção da cidadania. In: CARLOS, A.F.A. (Org.). Novos caminhos da geografia. São Paulo, SP: Contexto, 1999.

FREIRE, P. Educação como prática da liberdade. Rio de Janeiro, RJ: Paz e Terra LTDA, 1967.

HARLEY, J. B. A nova história da Cartografia. O Correio da Unesco, v.9, n.8, p.4-9, 1991.

KAERCHER, N.A. A geografia é o nosso dia a dia. In: CASTROGIOVANNI, A.C. et al. Geografia em sala de aula, práticas e reflexões. Porto Alegre, RS: Associação dos Geógrafos Brasileiros, 1998.

KOZEL, S. Mapas Mentais: Dialogismo e Representações. $1^{\text {a }}$ ed. Curitiba, PR: Appris, 2018.

OLIVEIRA, R.C. S. Terceira Idade: do repensar dos limites aos sonhos possíveis. São Paulo, SP: Paulinas, 1999.

RELPH, E. C. As bases fenomenológicas da Geografia. Geografia. v.4, n 7, 1-25, abril, 1979.

RICHTER, D. O mapa mental no ensino de geografia: Concepções e propostas para o trabalho docente. São Paulo, SP: Cultura Acadêmica, 2011.

SANTOS, M. A Natureza do Espaço: Técnica e Tempo, Razão e Emoção. São Paulo, SP: Edusp, 2002.

SUERTEGARAY, D. M. A. Espaço Geográfico Uno e Múltiplo. Scripta Nova, Barcelona, v.93, 2001.

TUAN, Y. F. Espaço e Lugar: a perspectiva da experiência. São Paulo, SP: DIFEL, 1983.

TUAN, Y. F. Topofilia: um estudo da percepção, atitudes e valores do meio ambiente. Trad. Lívia de Oliveira. São Paulo, SP: Difel, 2012. 